\title{
PENGEMBANGAN PEMBELAJARAN SEJARAH UNTUK MENINGKATKAN MINAT PESERTA DIDIK MELALUI MODEL KONTEKSTUAL
}

\author{
Akbar Maulana Azhari \\ Program Studi Pendidikan Sejarah FKIP Universitas Lambang Mangkurat Banjarmasin \\ Email: 1710111210003@mhs.ulm.ac.id
}

\begin{abstract}
Abstrak: Sejarah memiliki arti penting pada masa kini dan masa lalu dalam pembentukan watak dan rasa Nasionalisme sebuah Bangsa dan rasa kebangsaan dan cinta tanah air. Peranan mata pelajaran Sejarah disekolah dalam rangka mendidik siswa agar menjadi pribadi yang menghargai nilai sejarahnya. Pesan yang terkandung didalam pembelajaran Sejarah diharapkan dapat menimbulkan rasa Nasionalisme terhadap Bangsa nya sendiri, sehingga dimasa yang akan datang menjadi Bangsa yang maju karena tidak melupakan peristiwa Sejarah sebagai pembelajaran dimasa yang akan datang. Dengan melakukan sebuah Pengembangan Pembelajaran Sejarah Melalui Model Kontekstual.

Kemampuan berpikir sangat erat kaitannya dengan Pembelajaran Sejarah. Sebagai alternatif model pembelajaran yang dapat digunakan dalam pembelajaran sejarah meningkatkan minat peserta didik adalah model kontekstual. Model ini adalah guru yang memberikan materi kepada peserta didik dengan mengkaitkan Sejarah masa lalu dan mengkaitkan dengan kejadian atau peristiwa masa sekarang.
\end{abstract}

Kata Kunci: Minat, Pembelajaran, Model pembelajran kontekstual

\section{PENDAHULUAN}

Masih rendahnya mutu lulusan mengharuskan lembaga pendidikan di tuntut untuk meningkatkan mutu lulusan dan layanan lembaga pendidikan karena semakin ketatnya persaingan dalam lapangan kerja. Salah satu implikasi globalisasi dalam pendidikan yaitu adanya deregulasi yang memungkinkan peluang lembaga pendidikan asing membuka sekolahnya di Indonesia. Oleh karena itu persaingan antar lembaga penyelenggara pendidikan dan pasar kerja akan semakin berat. Mengantisipasi perubahan-perubahan yang begitu cepat serta tantangan yang semakin besar dan kompleks, tiada jalan lain bagi lembaga pendidikan kecuali hanya mengupayakan segala cara untuk meningkatkan daya saing lulusan serta produk-produk akademik dan layanan lainnya, yang antara lain dicapai melalui peningkatan mutu pendidikan. 
Lemahnya sumber daya manusia hasil pendidikan juga mengakibatkan lambannya Indonesia bangkit dari keterpurukan ekonomi yang merosot secara signifikan di tahun 1998. Namun saat fokus negara ASEAN lain sudah pulih, Indonesia masih belum mampu melakukan recovery dengan baik. Hal ini menandakan pendidikan di Indonesia masih tertinggal dengan Negara ASEAN lainnya. Pendidikan merupakan sarat penting dalam pertumbuhan ekonomi melalui peningkatan sumber daya manusia. Rendahnya kemampuan guru dalam mengemas dan melaksanakan proses belajar mengajar Sejarah agar tidak hanya membahas tentang masa lalu namun mengaitkannya dengan masa sekarang menjadi penyebab rendahnya kualitas proses pembelajaran di sekolah. Maka dari itu model pembelajaran kontekstual sangat membantu guru agar memberikan materi yang tidak monoton dan membuat siswa bosan. Salah satu faktor keberhasilan pembelajaran sangat tergantung dari kemampuan seorang pengajar atau guru dalam melaksanakan atau mengemas proses pembelajaran sehingga menghasilkan sesuatu yang sesuai dengan apa yang diinginkan pada tujuan pendidikan.

Guru merupakan aktor penting yang besar pengaruhya terhadap proses dan hasil belajar, bahkan sangat menentukan berhasil tidaknya peserta didik dalam belajar. Tugas guru tidak hanya menyampaikan informasi kepada peserta didik, tetapi harus dilatih sebagai fasilitator yang bertugas dalam memberikan kemudahan belajar (facilitate of learning) kepada seluruh peserta didik, agar mereka dapat belajar dalam suasana yang menyenangkan, gembira, penuh semangat, tidak cemas, dan terbuka.

\section{MENIGKATKAN MINAT PESERTA DIDIK}

Minat merupakan salah satu aspek psikis manusia yang dapat mendorong untuk mencapai tujuan. Seseorang yang memiliki minat terhadap suatu obyek, cenderung memberikan perhatian atau merasa senang yang lebih besar kepada obyek tersebut. Namun apabila obyek tersebut tidak menimbulkan rasa senang. Untuk mencapai prestasi yang baik disamping kecerdasan juga minat, sebab tanpa adanya minat segala kegiatan akan dilakukan kurang efektif dan efesien (Aritonang, 2008). Pengertian Minat menurut Tidjan (1976:71) adalah gejala psikologis yang menunjukan pemusatan perhatian terhadap suatu obyek sebab ada perasaan senang. Dari pengertian tersebut jelaslah bahwa minat itu sebagai pemusatan perhatian atau reaksi terhadap suatu obyek seperti benda tertentu atau situasi tertentu yang didahului oleh perasaan senang terhadap obyek tersebut.(Kartika, 2004) 
Keberhasilan pembelajaran dapat dicapai bila elemen-elemen terkait dapat dilaksanakan dengan baik. Antara lain yang akan dibahas dalam makalah ini adalah bagaimana mengupayakan keberhasilan pembelajaran dengan meningkatkan minat belajar siswa dengan menggunakan media pembelajaran(Nurdin et al., 2011).

Minat belajar atau dorongan untuk belajar didapat dari suasana pembelajaran yang akan memberikan motivasi dan kebebasan dalam mengeksplorasi atau menganalisis pengalaman belajar. Desain pembelajaran yang kondusif akan memberikan kebebasan mengekspresikan ide dan motivasi belajar mandiri (Susanto, 2006)

Strategi pembelajaran yang digunakan hendaklah tidak mematikan kreatifitas dan memaksa peserta didik hanya untuk menghafal fakta dalam buku teks. Sejarah sudah saatnya diajarkan dengan cara yang berbeda, kebekuan pembelajaran yang terjadi seringkali dikarenakan rendahnya kreatifitas dalam pembelajaran sejarah. Sebagai akibatnya kejenuhan seringkali menjadi faktor utama yang dihadapi guru dalam mengajarkan sejarah dan siswa dalam belajar sejarah (Heri Susanto, 2014).

Minat berperan sangat penting dalam kehidupan peserta didik dan mempunyai dampak yang besar terhadap sikap dan perilaku. Siswa yang berminat terhadap kegiatan belajar akan berusaha lebih keras dibandingkan siswa yang kurang berminat (Ilmiyah, Utaminingsih, \& Oktavianti, 2015).

Pembelajaran kontekstual, menurut Blanchard, merupakan suatu konsepsi pembelajaran yang membantu guru/dosen dalam mengkaitkan materi kuliah dengan kehidupan nyata, dan memotivasi siswa/mahasiswa membuat hubungan antara pengetahuan yang dipelajarinya dengan kehidupan mereka (Edy Supriyadi, 2007).

Ada beberapa macam cara yang dapat guru lakukan untuk membangkitkan minat anak didik sebagaiberikut:

1. Membandingkan adanya suatu kebutuhan pada diri anak didik, sehingga dia rela belajar tanpapaksaan.

2. Menghubungkan bahan pelajaran yang diberikan dengan persoalan pengalaman yang dimiliki anak didik, sehingga anak didik mudah menerima bahan pelajaran.

3. Memberikan kesempatan kepada anak didik untuk mendapatkan hasil belajar yang baik 
dengan cara menyediakan lingkungan belajar yang kreatif dan kondusif. 4. Menggunakan berbagai macam bentuk dan teknik mengajar dalam konteks perbedaan individual anak didik (Djamarah, 1994).

\section{MODEL KONTEKSTUAL}

Pembelajaran kontekstual adalah sebuah sistem yang merangsang otak untuk menyusun pola-pola yang mewujudkan makna. Lebih lanjut, Elaine mengatakan bahwa pembelajaran kontekstual adalah suatu sistem pembelajaran yang cocok dengan otak yang menghasilkan makna dengan menghubungkan muatan akademis dengan konteks dari kehidupan sehari-hari siswa (Elaine B. Johnson, 2008)

CTL adalah pembelajaran yang memungkinkan terjadinya proses belajar di mana siswa menggunakan pemahaman dan kemampuan akademiknya dalam berbagai konteks dalam dan luar sekolah untuk memecahkan masalah yang bersifat simulatif ataupun nyata, baik sendiri-sendiri maupun bersama-sama (Howey R, Keneth, 2001)

Pembelajaran kontekstual (Contextual Teaching and Learning) adalah konsep belajar yang membantu guru mengaitkan antara materi yang diajarkan dengan situasi dunia nyata siswa dan mendorong siswa membuat hubungan antara pengetahuan yang dimilikinya dengan penerapannya dalam kehidupan mereka sehari-hari. Menurut Suherman, Erman (2002:5) menyatakan bahwa terdapat 7 prinsip utama dalam pembelajaran kontekstual, yaitu:

1. Kontruktivisme (Contructivism) Contructivism (kontruktivisme) merupakan landasan berfikir (filosofi) dari pendekatan kontekstual, yaitu bahwa pengetahuan dibangun oleh manusia sedikit demi sedikit, yang hasilnya diperluas melalui konteks yang terbatas (sempit) dan tidak sekonyongkonyong. Pengetahuan bukanlah seperangkat fakta-fakta, konsep atau kaidah yang siap untuk diambil dan diingat. Manusia harus mengkonstuksi pengetahuan itu dan memberi makna melalui pengamatan nyata.

2. Menemukan (Inquiry) Menemukan merupakan bagian inti dari kegiatan pembelajaran berbasis kontekstual. Pengetahuan dan keterampilan yang diperoleh peserta didik diharapkan bukan hasil mengingat seperangkat fakta-fakta tetapi hasil menemukan sendiri. Guru harus selalu merancang kegiatan yang merujuk pada kegiatan menemukan, apapun materi yang diajarkan. 
3. Bertanya (Questioning) Pengetahuan yang dimiliki seseorang, selalu bermula dari "bertanya". Questioning merupakan strategi utama pembelajaran yang berbasis kontekstual. Bertanya dalam pembelajaran dipandang sebagai kegiatan guru untuk mendorong, membimbing, dan menilai kemampuan berfikir peserta didik.

4. Masyarakat Belajar (Learning Community) Konsep lerning community menyarankan agar hasil pembelejaran diperoleh dari kerjasama dengan orang lain. Hasil belajar diperoleh dari "sharing" antar teman, antar kelompok, dan antara yang tahu ke yang belum tahu. Di ruang ini, di kelas ini, di sekitar ini, juga orang-orang yang ada diluar sana, semua anggota masyarakat belajar. Dalam kelas pembelajaran kontekstual, guru disarankan selalu melaksanakan pembelajaran dalam kelompokkelompok belajar. Peserta didik dibagi dalam kelompok-kelompok belajar yang anggotanya heterogen. Yang pandai mengajari yang lemah, yang tahu memberi yang belum tahu, yang cepat menangkap mendorong temannya yang lambat, yang mempunyai gagasan segera memberi usul, dan seterusnya. Vygotsky (Wartono, et.al. 2004:19) mengemukakan bahwa siswa belajar melalui interaksi dengan orang dewasa atau teman sebaya yang lebih mampu. Hal ini sejalan dengan ide Blancard (Wartono, et.al. 2004:19) bahwa strategi CTL mendorong siswa belajar dari sesama teman dan belajar bersama.

5. Pemodelan (Modeling) Komponen pembelajaran kontekstual selanjutnya adalah pemodelan. Maksudnya, dalam sebuah pembelajaran keterampilan atau pengetahuan tertentu, ada model yang bisa ditiru. Model itu bisa berupa cara mengoperasikan sesuatu, cara melempar bola dalam olahraga, contoh karya tulis, cara melafalkan bahasa inggris, dan sebagainya. Dalam pendekatan pembelajaran kontekstual, guru bukan satu-satunya model. Model dapat dirancang dengan melibatkan peserta didik.

6. Refleksi (Reflecsion) Refleksi juga bagian penting dalam pembelejaran dengan pendekatan kontekstual. Refleksi adalah cara berpikir tentang apa yang baru dipelajari atau berpikir kebelakang tentang apa-apa yang sudah kita lakukan dimasa lalu. Peserta didik mengendapkan apa yang merupakan pengayaan atau revisi dari pengetahuan sebelumnya. Refleksi merupakan respon terhadap kejadian, aktivitas atau pengetahuan yang baru diterima

7. Penilaian yang Sebenarnya (Authentic Assesment) Assesment adalah proses pengumpulan berbagai data yang bisa memberikan gambaran perkembangan belajar siswa. Gambaran perkembangan belajar siswa perlu diketahui oleh guru agar bisa memastikan bahwa siswa mengalami proses pembelajaran yang benar. Apabila data yang dikumpulkan guru mengidentifikasikan bahwa siswa mengalami kemacetan 
dalam belajar, maka guru segera mengambil tindakan yang tepat agar siswa terbatas dari kemacetan belajar.

Karakteristik Pembelajaran Kontekstual Menurut Johnson dalam Nurhadi (2002 : 13), ada 8 komponen yang menjadi karakteristik dalam pembelajaran kontekstual, yaitu sebagai berikut :

1. Melakukan hubungan yang bermakna (making meaningfull connection). Siswa dapat mengatur diri sendiri sebagai orang yang belajar secara aktif dalam mengembangkan minatnya secara individual, orang yang dapatbekerja sendiri atau bekerja dalam kelompok, dan orang yang dapatbelajar sambil berbuat (learning by doing).

2. Melakukan kegiatan-kegiatan yang signifikan (doing significant work). Siswa membuat hubungan-hubungan antara sekolah dan berbagai konteks yang ada dalam kehidupan nyata sebagai pelaku bisnis dan sebagai anggota masayarakat.

3. Belajar yang diatur sendiri (self-regulated learning). Siswa melakukan kegiatan yang signifikan : ada tujuannya, ada urusannya dengan orang lain, ada hubungannya dengan penentuan pilihan, dan ada produknya atau hasilnya yang sifatnya nyata.

4. Bekerja sama (collaborating). Siswa dapat bekerja sama. Guru dan siswa bekerja secara efektif dalam kelompok, guru membantu siswa memahami bagaimana mereka saling mempengaruhi dan salingberkomunikasi.

5. Berpikir kritis dan kreatif (critical and creative thinking). Siswa dapat menggunakan tingkat berpikir yang lebih tinggi secara kritis dan kreatif : dapat menganalisis, membuat sintesis, memecahkan masalah, membuat keputusan, dan menggunakan logika dan bukti-bukti.

6. Mengasuh atau memelihara pribadi siswa (nurturing the individual). Siswa memelihara pribadinya : mengetahui, memberi perhatian, memberi harapan- harapan yang tinggi, memotivasi dan memperkuat diri sendiri. Siswa tidak dapat berhasil tanpa dukungan orang dewasa.

7. Mencapai standar yang tinggi (reaching high standard). Siswa mengenal dan mencapai standar yang tinggi : mengidentifikasi tujuan dan memotivasi siswa untuk mencapainya. Guru memperlihatkan kepada siswa cara mencapai apa yang disebut "excellence".

8. Menggunakan penilain autentik (using authentic assessment). Siswa menggunakan pengetahuan akademis dalam konteks dunia nyata untuk suatu tujuan yang bermakna. 


\section{PENUTUP}

Kontekstual menekankan pada guru pada saat dikelas mampu untuk memberikan materi Sejarah kepada peserta didik tidak hanya membahas tentang masa lalu guru juga harus mampu mengaitkan peristiwa sejarah pada masa lampau dengan kejadian pada masa sekarang agar pembelajaran dikelas tidak monoton dan membuat peserta didik akhirnya bosan untuk menyimak materi yang diberikan. 


\section{DAFTAR PUSTAKA}

Heri Susanto. 2014. Seputar Pembelajaran Sejarah: Isu, Gagagasan, dan Strategi Pembelajaran. Yogyakarta: Penerbit Aswaja Pressindo

Haryanto, S. P. 2013. Pengertian Minat Belajar. Pengertian Minat Belajar AJARAN 20122013.

Sabandar, Josua. (2003). Pendekatan Kontekstual Dalam Pembelajaran Matematika. Bandung: Universitas Pendidikan Indonesia.

Suherman, Erman. (2002). Pendekatan Kontekstual (Contextual Teaching and Learning. Jakarta: Depdiknas

Blanchard, Alan. (2001). Contextual teaching and learning. Surabaya: Postgraduate Program of State University of Surabaya.

Nurhadi. (2003). Pembelajaran kontekstual. Jakarta: Dit. PLP Depdiknas

Nurhadi. (2002) Pendekatan Kontekstual (Contextual Teaching and Learning. Jakarta: Departemen Pendidikan Nasional, Direktorat Jenderal Pendidikan Dasar dan Menengah, Direktorat PLP.

Eveline Siregar dan Hartini Nara. (2011). Teori Belajar dan Pembelajaran. (Bogor: Ghalia Indonesia,

Lukmanul Hakiim. (2009). Perenncanaan Pembelajaran. Bandung: Wacana Prima.

Depdiknas. (2003). Pembelajaran dan Pengajaran Kontekstual. Jakarta: Direktorat Sekolah Lanjutan Pertama Direktorat Jenderal Pendidikan Dasar dan Menengah.

\section{JURNAL:}

Pembelajaran Contextual Teaching and Learning Untuk Meningkatkan Mutu Hasil Pembelajaran $\begin{array}{lllll}\text { diakses } & \text { tanggal } & 25 & \text { april } & 2020\end{array}$ raniry.ac.id/index.php/Pionir/article/download/4589/3015

Penggunaan Model Pembelajaran Kontekstual Untuk Menigkatkan Kemampuan Pemahaman $\begin{array}{llllll}\text { Matematika siswa sekolah dasar } & 2020\end{array}$ https://media.neliti.com/media/publications/266435-penggunaan-model-pembelajaran-kontekstuae3a63f63.pdf 